\title{
Sustainability Status of Batik Small and Medium Enterprises (SME) in Jember Regency
}

\author{
Dewi Kurniawati* \\ Departement of Agribusiness \\ Management \\ Politeknik Negeri Jember \\ Jember, Indonesia \\ dewi_kurniawati@polije.ac.id
}

\author{
Oktanita Anggraeni \\ Departement of Agribusiness \\ Management \\ Politeknik Negeri Jember \\ Jember, Indonesia \\ oktanita@polije.ac.id
}

\begin{abstract}
Sustainable development is a development that seeks to fulfill the current need, without decreasing the futures generation's ability to fulfill their needs. There are three main reasons why economic development must be sustainable, namely economic theory, socio-environmental, social inequalities [2]. This purposes of this reseacrh was to determine the sustainability status of Batik Small and Medium Enterprises (SME) in Jember Regency in terms of ecological, economic and social dimensions. The method used in this research is multidimensional scaling (MDS) analysis with the Rap-fish (Rapid Appraissal for Fisheries) method. The results of the analysis show that the status of sustainability in the ecological dimension with a sustainability index of 63.07 , economy with a sustainability index of 73.22 and social with a sustainability index of 66.97 are in the position of a moderately sustainable ordination scale. Meanwhile, a multidimensional analysis shows that the sustainability status of Jember Batik SME is in a fairly sustainable status with a sustainability status index of 67.7 so it means that to maintain and improve the sustainability status it is necessary to improve the attributes that affect the improvement of the sustainability status.
\end{abstract}

Keywords — sustainability, batik, multidimensional scaling

\section{INTRODUCTION}

The development and growth of the Micro Small and Medium Enterprises (MSME) according to [1] about the Micro Small and Medium Enterprises Article 3 mentioned that the Micro Small and Medium Enterprises has an objective to grow and develop their business to growth national economic matters based on the equitable economic democracy.

The Small and Medium Enterprises sustainability in this recent year has become the interesting thing to discuss with academicians and the business actors. Sustainable development is a development that attempted to fulfill the current need without decreasing the futures generation's ability to fulfill their needs. At least, there are three main reasons why economic development should be sustainable. The first, from the point of view of leading economic theorists, the idea of sustainable growth needs to be put forward in order to achieve the conditions necessary and sufficient for achieving sustainable development; second, the idea of boundaries is the basis of efforts to determine the social boundaries of the environment in which economic development takes place; third, addressing Third World conditions, social inequality and questions related to the meaning of the concept of development as the main focus [2].
Batik industry is the source of community income in several cities such as Solo, Jogja, Pekalongan, and Jember Regency. The batik industry in the city of Jember still uses wax, excessive synthetic dyes, and the recycling of waste or raw materials is not carried out optimally by the craftsmen of Batik Jember. The batik industry is an industry that has a potential to produce a waste that contains heavy metal and harmful liquid waste that caused environmental pollution [3].

The study of sustainable production in terms of batik production eco-efficiency studies has been carried out [4]; [5]. The result shows that in general, batik industry still not efficient in using the materials and the resources. If it is related to the wastewater treatment, it still becomes the problem in almost the entire batik production center now on. The conditions of batik industry that is in the form of a small medium industry $(S M I)$ make it very difficult to build a water waste treatment plant $(W W T P)$ that needs infrastructure cost, skill, and a high operating cost. So that, the technology required by batik industry is the appropriate technology which has a simple design, easy to operate, and low cost.

Along with the increasing of the environmental damage caused by the economic development and the additional industry, the sustainability is needed in each consideration to determine a policy. Based on these problems, the United Nations $(U N)$ encourages to make for changes in production and consumption pattern into sustainable production and consumption through sustainable development goals.

Sustainable production processes not only concern to the side effect of the water waste process, it also focuses on how to treat the produced waste so that it can be used for other needs. The market condition and the low-profit income make the batik craftsmen have not gave enough attention to the environmental aspect. Because of that, it is very important for the craftsmen of batik Jember small and medium enterprises to pay attention on several sustainability aspects in each production process in order to create a suitable environment, economic, and the social culture. Based on those matters, the objective of this research is to know the sustainability status of Jember Batik Small and Medium Enterprises (SME) in terms of the ecological, economic, and social dimensions.

\section{RESEARCH METHODS}

The quantitative descriptive method was used in this research. This research was conducted on a purpose in Jember 
regency and the entrepreneur of batik Jember as the population. The sampling using a simple random sampling technique. [6] states that simple random sampling is a sampling technique in a sampling unit that is used to obtain samples directly. Therefore each sampling unit as the smaller population element has the same opportunity to be a sample or represent the population. It is conducted if the population is homogeneous.

TABLE I. SUSTAINABILITY STATUS CATEgORY OF JEMBER BATIK SMALL AND MEDIUM ENTERPRISES (SME) BASED ON THE INDEX VALUE OF RAP- SMALL BUSINESS PREVENTS BATIK JEMBER WITH MDS TECHNIQUE ANALYSIS

\begin{tabular}{|r|r|}
\hline Index Value & Sustainability Status \\
\hline $\mathbf{0 , 0 0}-\mathbf{2 5 , 0 0}$ & Bad (not sustainable) \\
\hline $\mathbf{2 5 , 0 1}-\mathbf{5 0 , 0 0}$ & Less (less sustainable) \\
\hline $\mathbf{5 0 , 0 1}-\mathbf{7 5 , 0 0}$ & Enough (fairly sustainable) \\
\hline $\mathbf{7 5 , 0 1 - \mathbf { 1 0 0 , 0 0 }}$ & Good (very sustainable) \\
\hline
\end{tabular}

TABLE II. SUSTAINABILITY StATUS ATtRIBUTES OF JEMBER BATIK SMALL AND MEDIUM ENTERPRISES (SME) BASED ON THE ECOLOGICAL, ECONOMIC, AND SOCIAL DIMENSIONS

\begin{tabular}{|l|l|}
\hline No & \multicolumn{1}{|c|}{ Sustainability Attributes } \\
\hline & Ecological Dimension \\
\hline 1. & Waste utilization \\
\hline 2. & Waste quantity \\
\hline 3. & Waste quality \\
\hline 4. & Location of waste disposal \\
\hline 5. & \multicolumn{1}{|c|}{ Distance from business location and residential housing } \\
\hline 6. & The knowledge of ecological impact \\
\hline & Economic Dimension \\
\hline 7. & Market position and competitiveness \\
\hline 8. & Partnership \\
\hline 9. & Product marketing area \\
\hline 10. & Production stability \\
\hline 11. & Batik diversity or excellent potential \\
\hline 12. & The profit of Jember Batik Small and Medium Enterprises (UKM) \\
\hline & Social Dimension \\
\hline 13. & Labor absorption level \\
\hline 14. & Occupational health and safety \\
\hline No & Sustainability Attributes \\
\hline 15. & Existence of Jember batik actor \\
\hline 16. & Knowledge of sustainable Jember batik production \\
\hline 17. & $\begin{array}{l}\text { The effect of Jember batik towards the social culture of the } \\
\text { community }\end{array}$ \\
\hline 18. & $\begin{array}{l}\text { Social conflict of Jember Batik Small and Medium Enterprises } \\
\text { (UKM) }\end{array}$ \\
\hline
\end{tabular}

${ }^{\text {b. }}$ Source: Observation result in several Jember Batik Small and Medium Enterprises (SME) at Jembe Regency (2020)

The data analysis method used in this research is multidimensional scaling (MDS) with Rap-Fish (Rapid Appraisal for Fisheries) modified into Rap-Small Business Prevents Jember Batik (Rapid Appraisal for Small Business Prevents Jember Batik). The sustainability status of Jember batik small and medium enterprises (SME) will be reviewed by three dimensions namely the ecological, economic, and social dimensions with multidimensional scaling (MDS) approach which is the development of Rap fish method. The modified results of the Rapfish program (Rapid Assessment Techniques for Fisheries) developed by the Fisheries center will produce the Jember Rap batik SME approach [7]. In the development of this method, nowadays it can be used to assess various sustainability. Sustainability status analysis using Rap-Small Business Prevents Batik Jember has three dimensions specifically the ecological, economic, and social dimensions. Further, those three dimensions will be processed by multidimensional scaling (MDS) technique.

\section{RESULT AND DISCUSSIONS}

The sustainability status of Jember batik small and medium enterprises (SME) will be reviewed by three sustainable dimensions namely the ecological, economic, and social dimensions. Rap-ordination Jember Batik SME analysis, Leverage of Attributes analysis, and Monte Carlo analysis will be conducted to each dimension to see the sustainability status per dimension. The sustainability status index starting from the value of 0-100.

\section{A. Sustainability Status Analysis in Ecological Dimension} of Jember Batik Small and Medium Enterprises (SME)

1) Rap- Ordination Jember Batik SME Analysis in ecological dimension

Ecological dimension consists of six sustainable attributes, there are waste utilization, waste quantity, waste quality, location of waste disposal, the distance from business location and residential housing, and the knowledge of the ecological impact.

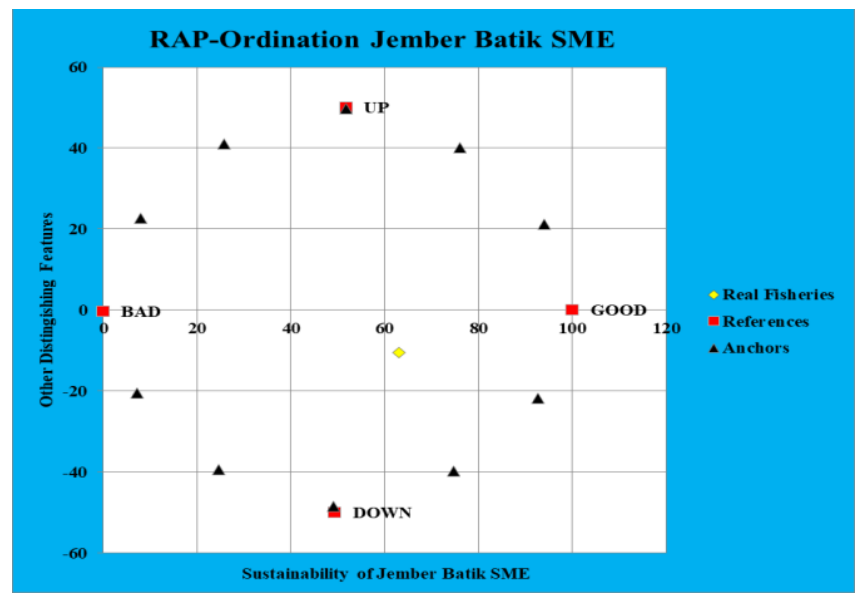

Fig. 1. Sustainability index in ecological dimension of Jember Batik Small and Medium Enterprises (SME)

Sustainability index in ecological dimension of Jember Batik Small and Medium Enterprises (SME) can be seen in Picture 1 . The attributes of ecological dimension considerated the effect of sustainability level and the development of Jember Batik Small and Medium Enterprises (SME). Based on the rapfish analysis result that has been modified into RapBatik Jember SME, the sustainability value of Jember Batik Small and Medium Enterprises (SME) specifically in ecological dimension is around 63,07 and it shows that the ecological dimension classified as sufficient sustainability status. The Rap-analysis Batik Jember SME result in ecological dimension is quite good analysis result because the stress value is 0.15 and $\mathrm{R}^{2}$ value is 0.94 . The allowed stress value is not greater than 0.25 and $\mathrm{R}^{2}$ value is not greater than 1. 
2) Leverage of Attributes Analysis in ecological dimension

Leverage of Attributes Analysis in ecological dimension was used to determine which attributes that gave a significant effect to the sustainability status in the development of Jember Batik Small and Medium Enterprises (SME). The sensitive attribute is an attribute that has a role for the sustainability status in the studied dimension where these attributes able to support and inhibit the sustainability status of Jember Batik Small and Medium Enterprises (SME) in ecological dimension aspect. The Root Mean Square (RMS) value indicates sensitive attributes. If the RMS value is $\geq 2 \%$ means that this attribute is categorized as sensitive attribute [9]. In this study, the RMS value is $\geq 2 \%$ in 5 attributes of ecological dimension. The sensitive attributes that have a bigger effect on the development sustainability of Jember Batik Small and Medium Enterprises (SME) are in the form of waste quality, the distance from business location and residential housing, and the knowledge of ecological impact. These three attributes have a very high RMS value compared with the other attributes.

The waste quality and the distance from business location and residential housing have the bigger effect on the sustainability of Jember Batik Small and Medium Enterprises (SME). It shows by the optimal waste utilization so that it does not pollute the environment. The distance from business location and residential housing is quite far so that the community does not need to worry about the waste impact from Jember Batik Small and Medium Enterprises (SME).

\section{3) Monte Carlo Analysis in ecological dimension}

Monte Carlo analysis is the advanced analysis in RapBatik Jember analysis. Monte Carlo analysis used to know and evaluate a random error impact of each attribute used to see the sustainability status of Jember Batik Small and Medium Enterprises (SME) development. Monte Carlo analysis of the ecological dimension shows quite good results (does not have a significant range of errors) as indicated by the accumulation of points (scatter plot) resulting from MDS repetition or ordination points. The position of the ordination points which is close to each other indicates that the result of 25 replication is in the value range of 58,75-66,04.

B. Sustainability Status Analysis in Economic Dimension of Jember Batik Small and Medium Enterprises (SME)

1) Rap-Ordination analysis Jember Batik SME in economic dimension

Economic dimension consists of 6 sustainability attributes namely: Market position and competitiveness, Partnership, Product marketing area, Production stability, Batik diversity or excellent potential, and the profit of Jember Batik Small and Medium Enterprises (SME).

Sustainability index in economic dimension of Jember Batik Small and Medium Enterprises (SME) can be seen in Picture 2.

The attributes of economic dimension considerated the effect of sustainability level and the development of Jember Batik Small and Medium Enterprises (SME). Based on the rapfish analysis result that has been modified into Rap-Jember Batik SME, the sustainability value of Jember Batik Small and Medium Enterprises (SME) specifically in economic dimension is around 73,22 and it shows that the economic dimension is classified as sufficient sustainability status. The Rap-Jember Batik SME analysis result in ecomonic dimension is quite good analysis result because the stress value is 0.14 and $R 2$ value is 0.94 . The allowed stress value is not greater than 0.25 and $\mathrm{R} 2$ value is not greater than 1 .

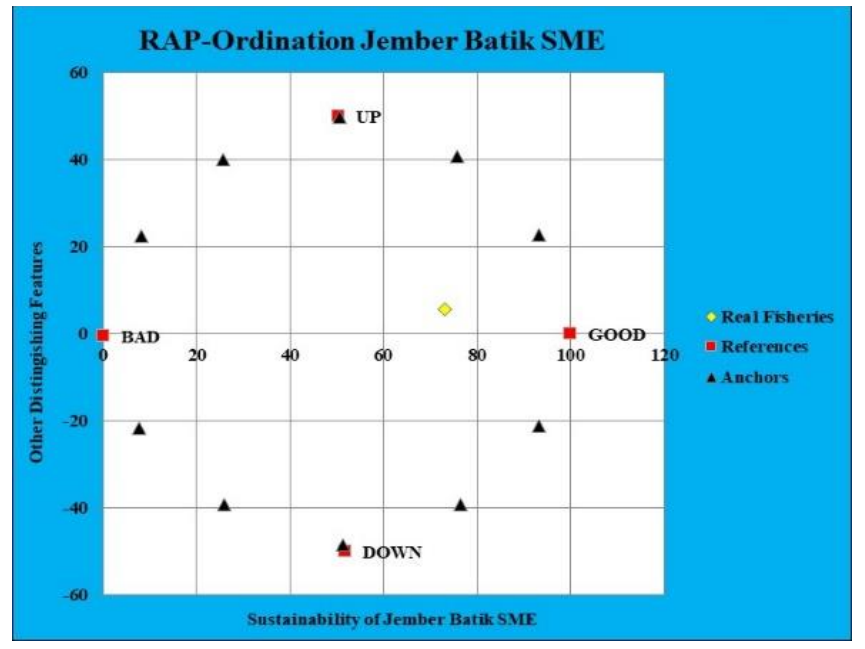

Fig. 2. Sustainability index in economic dimension of Jember Batik Small and Medium Enterprises (SME)

\section{2) Leverage of Attributes Analysis in economic dimension}

Leverage of Attributes Analysis in economic dimension used to determine which attributes that gave a significant effect on the sustainability status in the development of Jember Batik Small and Medium Enterprises (SME). The sensitive attribute is an attribute that has a role for the sustainability status in the studied dimension where these attributes able to support and inhibit the sustainability status of Jember Batik Small and Medium Enterprises (SME) in economic dimension aspect. The Root Mean Square (RMS) value indicates sensitive attributes, if the RMS value is $\geq 2 \%$ means that this attribute categorized as sensitive attribute [9]. In this study, the RMS value is $\geq 2 \%$ in all attributes of economic dimension. The sensitive attributes that have a bigger effect to the development sustainability of Jember Batik Small and Medium Enterprises (SME) are in the form of product marketing area, batik diversity or excellent potential, and the production stability. These three attributes have a very high RMS value compared with the other attributes.

The product marketing area has the greatest effect to the sustainability of Jember Batik Small and Medium Enterprises (SME). It shows by the product marketing that have already categorized in national market scale. Although it is not signifiicat, but there have been developments effort in Jember Batik Small and Medium Enterprises (SME) for a recent years. Further, Batik diversity and the production stability in Jember Batik Small and Medium Enterprises (SME) could also support its sustainability. This is shown in the variety of its batik with a good quality and also the increase volume of selling and ordering in a recent years.

\section{3) Monte Carlo analysis in economic dimension}

Monte Carlo analysis is the advanced analysis in RapBatik Jember analysis. Monte Carlo analysis used to know and evaluate a random error impact of each attributes used to 
see the sustainability status of Jember Batik Small and Medium Enterprises (SME) development.

Monte Carlo eceonomic dimension analysis shows quite good results (does not have a significant range of errors) as indicated by the accumulation of points (scatter plot) resulting from MDS repetition or ordination points. The position of the ordination points which is close to each other indicates that the result of 25 replication is in the value range of 66,01-75,07.

\section{Sustainability Status Analysis in Social Dimension of} Jember Batik Small and Medium Enterprises (SME)

\section{1) Rap-Ordination analysis Jember Batik SME in social} dimension

Social dimension consists of 6 sustainability attributes namely: labor absorption level, occupational health and safety, the local community relationship with Jember Batik Small and Medium Enterprises (SME), knowledge of sustainable Jember batik production, community perception towards Jember Batik Small and Medium Enterprises (SME), and community empowerment in Jember Batik Small and Medium Enterprises (SME).

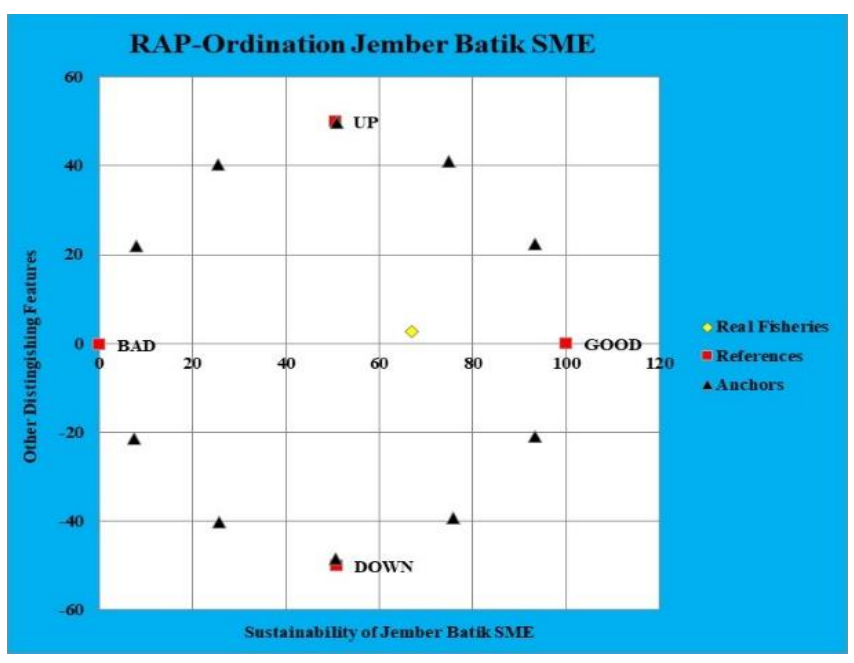

Fig. 3. Sustainability index in social dimension of Jember Batik Small and Medium Enterprises (SME)

Sustainability index in social dimension of Jember Batik Small and Medium Enterprises (SME) can be seen in Picture 3 . The attributes of social dimension considerated the effect of sustainability level and the development of Jember Batik Small and Medium Enterprises (SME). Based on the rapfish analysis result that has been modified into Rap-Jember Batik SME, the sustainability value of Jember Batik Small and Medium Enterprises (SME) specifically in social dimension is around 66,97 and it shows that the social dimension classified as sufficient sustainability status. The Rap-Jember Batik SME analysis result in social dimension is quite good analysis result because of the stress value is 0.15 and $R^{2}$ value is 0.94 . The allowed stress value is not greater than 0.25 and $\mathrm{R}^{2}$ value is not greater than 1 .

\section{2) Leverage of Attributes analysis in social dimension} Leverage of Attributes analysis in social dimension used to determine which attributes that gave a significant effect to the sustainability status in the development of Jember Batik Small and Medium Enterprises (SME). The sensitive attribute is an attribute that has a role for the sustainability status in the studied dimension where these attributes able to support and inhibit the sustainability status of Jember Batik Small and Medium Enterprises (SME) in social dimension aspect. The Root Mean Square (RMS) value indicates sensitive attributes, if the RMS value is $\geq 2 \%$ means that this attribute categorized as sensitive attribute [9]. In this study, the RMS value is $\geq 2 \%$ in all attributes of social dimension. The sensitive attributes that have a bigger effect to the development sustainability of Jember Batik Small and Medium Enterprises (SME) are in the form of local community relationship with Jember Batik Small and Medium Enterprises (SME), knowledge of sustainable Jember batik production, and community empowerment in Jember Batik Small and Medium Enterprises (SME). These three attributes have a very high RMS value compared with the other attributes.

Local community relationship with Jember Batik Small and Medium Enterprises (SME), has the biggest effect to the sustainability of Jember Batik Small and Medium Enterprises (SME). It shows by the harmonious relationship and win-win solution between the community and Jember Batik Small and Medium Enterprises (SME). Further, it proved by the local community empowerment to participate and develop batik product and Jember Batik Small and Medium Enterprises (SME). Moreover, community could also get the knowledge about sustainable batik production with a good quality and eco-friendly. Although the labor absorption is low, but by the existence of Jember Batik Small and Medium Enterprises (SME) the local community could obtain a skill and good relationship

\section{3) Monte Carlo analysis in social dimension}

Monte Carlo analysis is the advanced analysis in RapBatik Jember analysis. Monte Carlo analysis used to know and evaluate a random error impact of each attributes used to see the sustainability status of Jember Batik Small and Medium Enterprises (SME) development. Monte Carlo social dimension analysis shows quite good results (does not have a significant range of errors) as indicated by the accumulation of points (scatter plot) resulting from MDS repetition or ordination points. The position of the ordination points which is close to each other indicates that the result of 25 replication is in the value range of $63,62-72,26$.

\section{Sustainability Analysis of Jember Batik Small and Medium Enterprises (SME) using Multidimensional Scaling Method}

Sustainability analysis of Jember Batik Small and Medium Enterprises (SME) consist of 3 dimensions namely ecological, economic, and social dimensions. Further, it analyzed using RAP-Jember Batik SME with Multidimensional scaling (MDS) of each dimension. The results of the analysis show that the sustainability status in ecological dimension shows the result of Rap- Ordination Batik SME was around 63,07 and it means that this dimension is categorized in the fairly sustainable ordination scale. The ecological dimension has 6 sensitive attributes that show a quite good result or does not have a significant error range. This is indicated by the accumulation of points (scatter plot) resulting from MDS repetition that is around 58,75-66,04 or the ordination points were close to each other.

The sustainability status in economic dimension shows the result of Rap- Ordination Batik SME was around 73,22 and it means that this dimension is categorized in the fairly 
sustainable ordination scale. Economic dimension has 6 sensitive attributes that show a quite good result or does not have a significant error range. It indicated by the accumulation of points (scatter plot) resulting from MDS repetition that is around $66,01-75,07$ or the ordination points were close to each other.

The sustainability status in social dimension shows the result of Rap-SME Batik Ordination was around 66,97 and it means that this dimension is categorized in the fairly sustainable ordination scale. Social dimension has 6 sensitive attributes that shows by a quite good result or does not have a significant error range. It indicated by the accumulation of points (scatter plot) resulting from MDS repetition that is around $63,62-72,26$ or the ordination points were close to each other.

After the index value of the sustainability status in each dimension, namely, the ecological, economic, social dimensions have been known, the index value of the sustainability status can be illustrated on the kite diagram as follows:

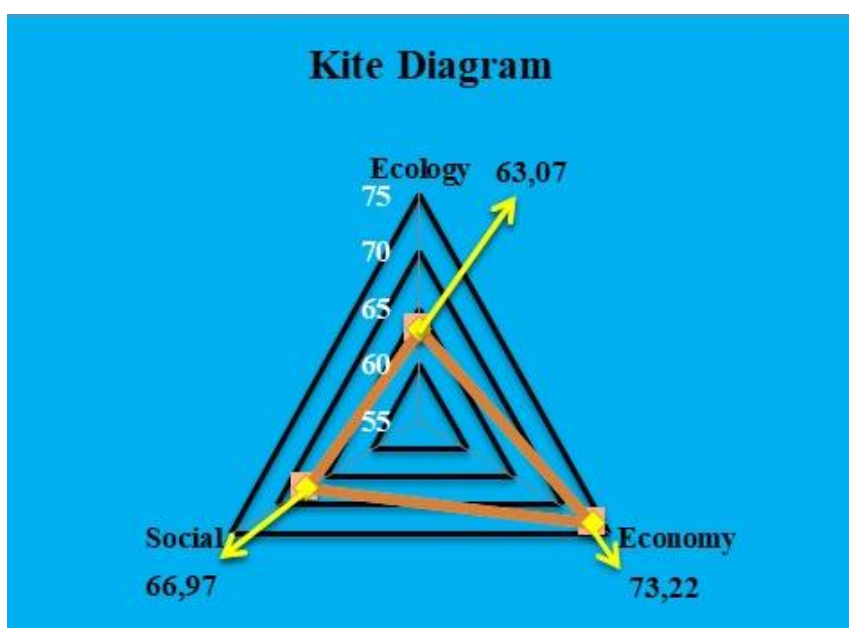

Fig. 4. Picture 4. Index value of the sustainability status of Jember Batik Small and Medium Enterprises (SME) using kite diagram

Based on Picture 4, it is known that the results of the multidimensional analysis above show that the sustainability status of Jember Batik Small and Medium Enterprises (SME) is in a fairly sustainable status with the index value of sustainability status around 67.75 , the value is on the ordination scale of 60.01 - 75.00. To maintain and improve future sustainability status, it is necessary to intervene (improve) the attributes that affect the improvement of the sustainability status. In addition, it is necessary to prioritize the attributes improvement in the sustainability dimension that has a lower sustainability index value. The improvements to those attributes should not only be carried out to the attributes that are sensitive to an increase in sustainability status, but also to the attributes that are not sensitive so that the sustainability status can be increased close to the 100 percent sustainability index value. Of course, considering financial capability, time, and energy.

\section{CONCLUSION}

The results of the analysis carried out on the sustainability status of the ecological dimension, it shows the results of the Rap-SME Batik Ordination of 63.07, which means that the dimension is still in a position of a fairly sustainable ordination scale. In the economic dimension, it shows the results of the Rap-SME Batik Jember Ordination of 73.22, which means that this dimension is still in a position of a fairly sustainable ordination scale. Meanwhile, the social dimension shows the results of the Rap-SME Batik Jember Ordination of 66.97, which means that the dimension is still in a position of a fairly sustainable ordination scale.

The results of the multidimensional analysis show that the sustainability status of Jember Batik Small and Medium Enterprises (SME) is in a fairly sustainable status with the index value of sustainability status around 67.75 , the value is on an ordination scale of $60.01-75.00$. To maintain and improve the future sustainability status, it is necessary to intervene (improve) the attributes that affect the improvement of the sustainability status. In addition, it is necessary to prioritize the attributes improvement in the sustainability dimension that has a lower sustainability index value. The improvements to those attributes should not only be carried out to the attributes that are sensitive to an increase in sustainability status, but also to the attributes that are not sensitive so that the sustainability status can be increased close to the 100 percent sustainability index value. Certainly, considering financial capability, time, and energy.

\section{ACKNOWLEDGMENT}

I would like to thank the Director of the Jember State Polytechnic (Polije) for providing motivation. Special thanks also to the Ministry of Education and Culture and P3M who provided this research through the 2020 PNBP funds. I also express my thanks especially to the research team who helped carry out the research. Many parties have provided motivation, advice and support for researchers in preparing this research. This research would not have been possible without their help, support and patience.

\section{REFERENCES}

[1] Undang-Undang Nomor 20 Tahun 2008 tentang Usaha Mikro, Kecil, dan Menengah Pasal 3. (t.thn.).

[2] F. D. Vivien, Sustainable development : An overview of economic proposals, Surveys and Perspectives Integrating Environment and Society, Vol.1/n 2, 1.2, 2008

[3] D. Kurniawan, Strategi Pengelolaan Air Limbah Sentra UMKM Batik yang Berkelanjutan di Kabupaten Sukoharjo. Jurnal Ilmu Lingkungan, 11(2), $62-72,2013$

[4] T. Murni, The Effect of Enterpreneurial Orientation to Low Cost Strategy, Differentiation Strategy, Sustainable Innovation and Performance of Small and Medium Enterprises (Studies at Batik Small and Medium Enterprises in East Java Province, Indonesia). Europan Journal of Business and Management, Vol. 9, No. 20, 8-16, 2017

[5] D. Sutisna MN, M.H.M. Saudi, Human Capital in Improving Creative Industrial Performance: A Study in the Creative Industry of Batik Trusmi, Cirebon Dstrict, West Java, International Journal of Engineering \& Technology, 7(4.34), 295-298, 2018

[6] S. Margono, Metodologi Penelitian Pendidikan, Jakarta : PT Rineka Cipta, 2010

[7] R. Yusuf, U. M. Tang, R. Karnila and U. Pato, Indeks and Sustainability Status of Economic Dimension for Wetland Fice Business in Siak Regency, Riau, Indonesia, Journal of Environmental Science and Technology, 12 (4): 177-185, 2019

[8] Khodijah, Sustainable Livelihoods of Fishermen Households Headed by Women (Case Study in Riau Islands Province of Indonesia). Asian Social Science, Vol.10, No.9, 187 - 196, 2014

[9] W.C. Dwipa P, S. Komariyah. Hr. C. Diartho, Sustainability of Village Business Agencies (BUMDesa) and Development Strategy in Pamekasan District. American Journal of Economics, 10 (1), 11 - 20, 2020. 